\title{
Development of forests in the former heathland landscape: changes in the habitat quality, structure of undergrowth, syntaxonomy of phytocoenoses and modern pollen deposition
}

\author{
Milosz Deptuła*, Anna Filbrandt-Czaja, Andrzej Nienartowicz, Dariusz Kamiński, Edyta Adamska, \\ Agnieszka Piernik, Anna Lewandowska-Czarnecka
}

Nicolaus Copernicus University, Faculty of Biology and Environmental Protection, Chair of Geobotany and Landscape Planning, Lwowska 1 St, 87-100 Toruń, Poland, *e-mail: deptula@umk.pl

Received: 22 November 2017 / Accepted: 4 May 2018

\begin{abstract}
This study presents changes in the quality of habitats between 1926 and 2013 in permanent units of forest division restored in the 19th century as a result of afforestation carried out in the landscape dominated by heaths and xerothermic grasslands. The research was conducted in the Zaborski Landscape Park, located in the north-western part of the Tuchola Forest - one of the largest forest complexes in Poland. Changes in the habitat quality were determined based on data included in seven consecutive inventory books. Assessment according to the 5-point quality scale was performed on the basis of average height reached by a pine forest stand of a certain age occurring in particular forest subsections. It has been found that the quality of habitat increased over 87 years by two classes, on average from IV to II. The number of species, especially deciduous trees and shrubs listed in inventory books, was an additional parameter expressing the habitat quality. The extent of habitat changes was also determined based on the types of syntaxa, which are represented by relevés forming the time series and made more or less at the same sites by different authors in 1961, 2002 and 2013, i.e. over the period of 52 years. Temporal changes in the structure of phytocoenoses and their syntaxonomic affiliation were determined using the classification and ordination methods. It has been found that in the study area and within the studied time horizon, there was a recession of dry coniferous forest which developed towards mesic (fresh) pine forests. Whereas within the fresh coniferous forest, there were transitions from the poor cladonietosum variant to the mesotrophic typicum variant, or from the typicum variant towards the fertile variant with a large contribution of Fagus sylvatica in the main tree layer and undergrowth. A change in the forest type from a pine monoculture to mixed pine-beech forest was also reflected in the spectrum of modern pollen deposition collected after annual exposures of Tauber traps. In this case, the observations were performed by the same research team over 15 years.
\end{abstract}

Key words: afforestation, Fagus sylvatica, landscape history, numerical ordination, pine forests, pollen analysis, Tuchola Forest Biosphere Reserve, syntaxonomy, understorey species richness.

\section{Introduction}

The structure of contemporary forests in Europe has been strongly affected by two economic activities in the past: deforestation and afforestation through planting of pine monocultures. Heaths and meadows were common ecosystems in the deforested areas of Central Europe, often used as grazing lands for livestock. After centuries of ag- ricultural use, open landscape has been afforested since the mid-19th century and forests have been reconstructed for economic, political or ecological reasons.

The process of forest development after afforestation of heathlands has been discussed by different authors (Berendse, 1990; Lauschner \& Rode, 1986; Rode, 1999a, b; von Oheimb et al., 2008). Changes in physical and chemical properties of soil affecting the process of forest growth 
have been most often addressed by scientists. In addition, some authors focused on woody plants (Zerbe \& Brande, 2003; Manning et al., 2004) or the overall plant species composition as part of the forest ecosystem, e.g. (Wallace et al., 1992; Koerner et al., 1997; Flinn \& Vellend, 2005; Amici et al., 2012).

In the 19th century, Pomerania was one of the most severely deforested regions in the Central European lowlands. Changes in afforestation observed in this part of the region during the last millennium were presented on maps (Ślaski, 1951) and the range of forests at the turn of the 18th and 19th century in the eastern part (referred to as Gdańsk Pomerania) was described (Zaborski, 1935). In the 19th century, a large area in this part of Pomerania (which at that time belonged to Prussia) was covered by heaths. As a result of political and economic processes, the extent of deforestation was so large that in some places the area was completely devoid of woods (Kozikowski, 1911). Sheep farming developed in deforested areas dominated by heaths and pioneer grasslands (Wielopolski, 1959).

In the second half of the 19th century, the Prussian government began to reconstruct the forest. Further extensive afforestation of the former agricultural lands and heathlands took place after World War I in German as well as in Polish parts of Pomerania. The extent of afforestation increased after World War II, when the whole territory between the Vistula and the Oder River was incorporated into the territory of Poland. The communist government began to remove war losses in forests and increased the forest area through afforestation of large landed estates. However, the preserved forests were heavily exploited as a consequence of an extended felling plan, clear cutting and introduction of pine monocultures on fertile habitats. By the end of the 1980s, especially after the change of the political and economic system, the forest management has become more pro-ecological. Biodiversity conservation became one of its guiding principles implemented through the increasing contribution of deciduous species.

Tuchola Forest was a large forest complex in Pomerania. Its deciduous trees were replaced by pine trees after incorporation into the Prussian State in the late 18th century. However, heaths and other non-forest communities developed over large areas in many places within this forest. This process took place mostly in the north-western part of Tuchola Forest, where Zaborski Landscape Park is currently located. Former maps of forest stands and inventory books of forest divisions have been preserved for this area. The process of afforestation recorded on historical maps and aerial photographs was described (Wilkoń-Michalska et al., 1999). Furthermore, annual pollen deposition has been monitored in the Zaborski Landscape Park since 1999 (Filbrandt-Czaja et al., 2012) and nearly hundred relevés of forest communities were made in the period since the 1960s (Sokołowski, 1965; Matuszkiewicz, 2007). Based on the analysis of a set of relevés from two periods (1961 and 2002), the directions of changes in the structure of forest communities occurring over the period of thirty-one years using the classical phytosociological method was described (Matuszkiewicz, 2007).

During the last several years, there has been a debate in the Polish ecology and forestry about an increase in the quality of forest habitats. The objective of this debate is to find an answer to the question whether the commonly observed changes in the species composition of forests are a manifestation of increased habitat quality and whether this increase is a real phenomenon resulting from climate change, eutrophication of habitats or regeneration of more fertile deciduous forest habitats. On the other hand, another question arises whether these changes may only be a seeming phenomenon, resulting from changes in the guidelines on the classification of forest habitats valid in different periods (Brzeziecki, 1999). To verify these hypotheses, changes in the habitat condition of some forest complexes located in Poland were investigated (Bernadzki et al., 1997; Sokołowski, 1991). Those were forests whose development has not been interrupted by a long-term nonforest phase and artificial reconstruction of forest on the heaths or other non-forest habitats. Furthermore, time frames of the previous observations were not long enough and the forest sites were evaluated based on the habitat quality only. Thus, our research addresses a new, previously not investigated process and the time frames of our analyses are longer compared to the previous studies. Our research covers also changes in other elements of forest communities such as understory, the overall species composition of phytocoenoses and modern pollen deposition.

Given the above differences in the research scope, we can say that our study aimed at determining to what extent changes in the habitat, defined based on the average height of a pine tree stand and related to its age (the habitat quality index), are observed over a long time series of the succession not yet studied in Poland, i.e. the development of forest reconstructed on heaths and psammophilous grasslands. Furthermore, our research aimed at verifying to what extent an increase in the habitat quality expressed by this most commonly used index in forest studies corresponds to changes in three other parameters of the forest community structure: 1 - undergrowth species richness , 2 - affinity with syntaxonomic units determined through the standard phytosociological method and numerical ordination, 3 composition of the modern pollen deposition.

The results of our research on the forest species composition were compared with observations of forest growth processes observed on heaths in other countries of Central Europe. 


\section{Material and methods}

\subsection{Study area}

The research was conducted in Tuchola Forest in northern Poland. The region covers ca. $5,000 \mathrm{~km}^{2}$ where pine monocultures dominate. Small areas of forest stands rich in deciduous species were preserved mostly in the eastern part of the forest complex.

Our study area is located in the northern part of Zaborski Landscape Park (Fig. 1). It is adjacent to the northern part of the Tuchola Forest National Park established

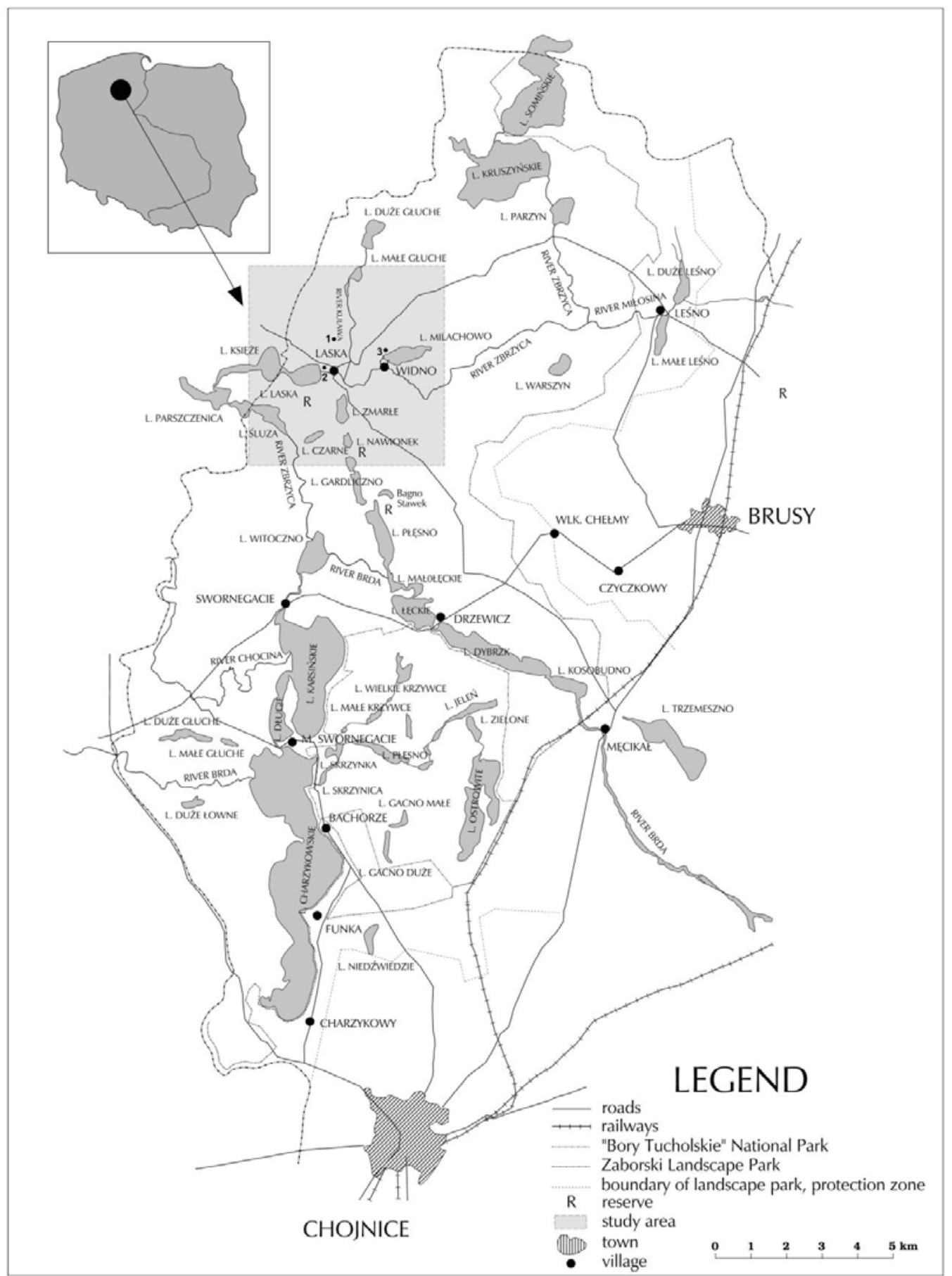

Figure 1. Location of the study area and sites of pollen traps (1 - Laska, pine forest (L-P-F); 2 - Laska, pine/broad-leaved forest (L-PB-F), 3 - Widno, broad-leaved forest (W-B-F)) 
in 1996, which is the largest park in the core areas of the polycentric Tuchola Forest Biosphere Reserve designated in 2010. In terms of administrative divisions, the study area is part of Brusy commune which is included in the district of Chojnice.

Forests in the northern part of the Zaborski Landscape Park belong to the Przymuszewo Forest Division, which was created in 1920. This forest division is managed by the Regional Directorate of State Forests (RDSF) in Torun.

Habitats of coniferous forest dominate in the area of the Przymuszewo Forest Division. They cover $62 \%$ of the total area, mixed coniferous forests cover $30 \%$, mixed forests $-7 \%$, and other forests $-1 \%$. Pinus sylvestris is the dominant tree species. Pine stands cover $95.5 \%$ of the forest area. Birch stands cover $2.0 \%$ of the total area, oak forest stands $-0.8 \%$, alder $-0.6 \%$, spruce $-0.6 \%$ and other species, including Fagus sylvatica $-0.5 \%$.

The study area (indicated in the Figure 1 by the shaded square) is dominated by fresh (mesic) Leucobryo-Pinetum and dry Cladonio-Pinetum pine coniferous forests. Moist coniferous forests Molinio-Pinetum and marshy coniferous forests Vaccinio uliginosi-Pinetum occur near the lakes and ground depressions. Deciduous forests cover much smaller area. These are mainly riparian forests in the valleys of rivers: Zbrzyca, Kłonecznica and Kulawa, i.e. tributaries of the 1 st and the 2 nd order of the Brda River. On the northern shore of the Milachowo Lake (on the slope of the lake channel), small areas of oak-hornbeam forest and acidophilous beech forest occur, classified by Sokołowski
(1965) as associations Galio-Carpinetum typicum and $\mathrm{Lu}$ zulo pilosae-Fagetum.

In the area of the Przymuszewo Forest Division, two Natura 2000 sites are located, designated based on the EU Birds Directive. There are also four Natura 2000 sites designated under the EU Habitats Directive, four nature reserves, 38 ecological lands and 69 natural monuments. The latter are represented by trees, including 14 pedunculate oaks and 8 European beeches.

\subsection{Analysis of habitat quality changes}

Changes in the habitat were based on data from forest surveys. The oldest inventory book presented a status of the forest stands in 1926. The map of forest stands with the location of 111 sampling plots was added to this document. A total of 87 sites were selected for further analysis. The excluded sites are located (after the state forest reform in 1973) in the Forest Division Osusznica of RDSF Szczecinek. Trees were measured on the plots and the results were included in the survey report. On the basis of these data, the quality of forest stands and habitats was assessed. The quality was determined by comparing the height of trees with the average height of a standard pine of the same age listed in timber tables. Until the 1950s, foresters assessing the habitat quality used forest abundance tables prepared by Schwappach (1908). Evaluations performed after World War II used extended tables prepared by Szymkiewicz $(1949,1971)$ on the basis of Schwappach's tables. In

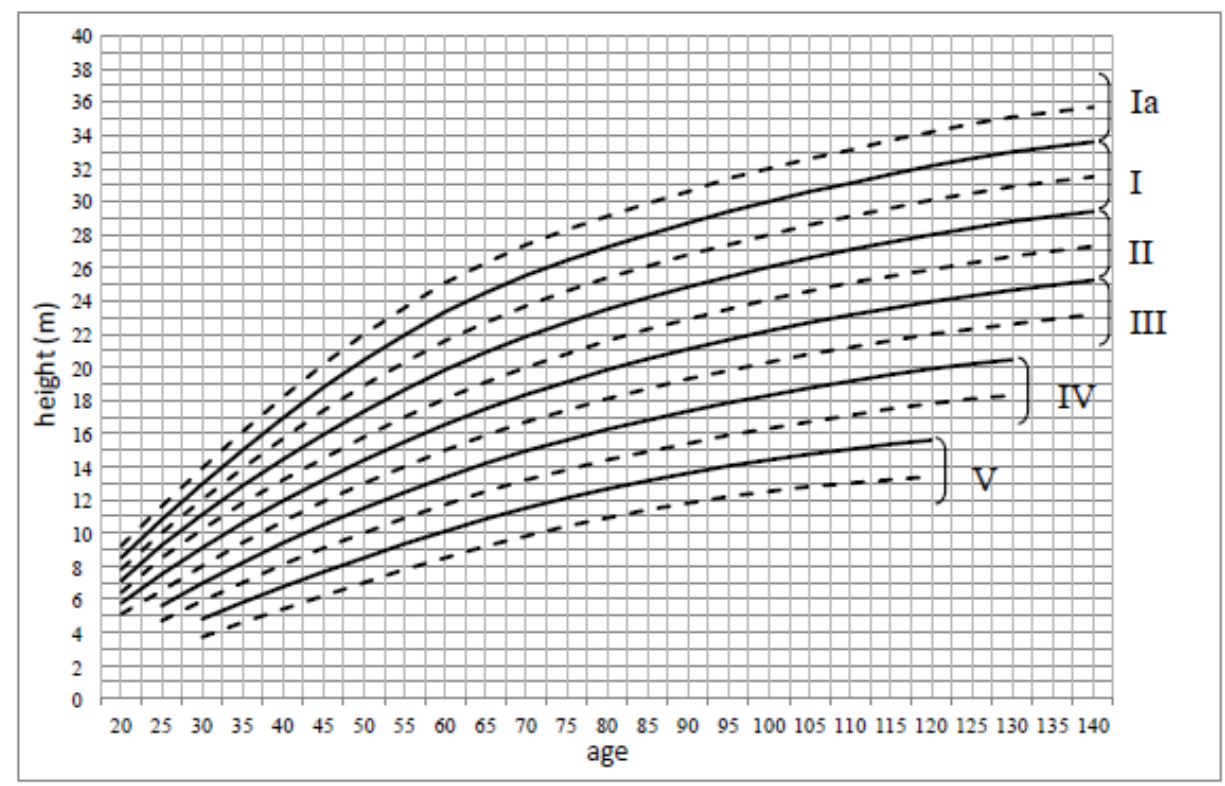

Figure 2. A scale of habitat quality related to the relationship between the average height of a forest stand and the age of a model pine stand (Szymkiewicz, 1971) 
our study classes I and Ia from Szymkiewicz' tables were combined into one class I. The I class is linked to the best habitat quality, whereas the V class - to the worst. Figure 2 presents a five-degree scale of habitat quality related to the relationship between the average height of a forest stand and the age of a model pine stand (Szymkiewicz, 1971).

Data on the habitat quality of each site after World War II came from the inventory books from the following years: 1953, 1966, 1976, 1988, 1999 and 2009. These data applied to the forest subdivision which covered the study area. The example of the location of related sites No. 44 and 45 in 1926 and subdivision 277f in 2009 according to inventory maps from those years are presented in Figure 3.
A transition matrix and a diagram showing changes in the habitat quality classes were prepared for each site based on the collected data.

\subsection{Analysis of changes in species composition of undergrowth}

Data on the undergrowth species composition were obtained based on the same, seven survey reports - in 1926 on plots and in subsequent years - on the forest subdivisions with these plots. Data were collated in a table, which contains the list of all species and the number of their occurrences in 1926, 1953, 1966, 1976, 1988, 1999 and 2009. The table contains also the number of coniferous

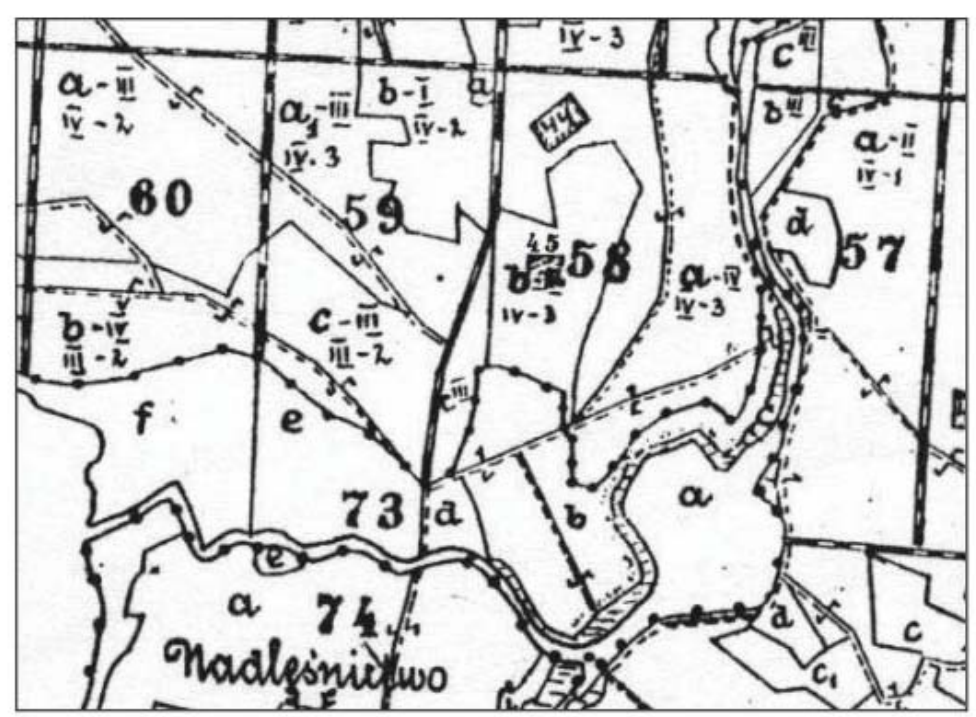

2009

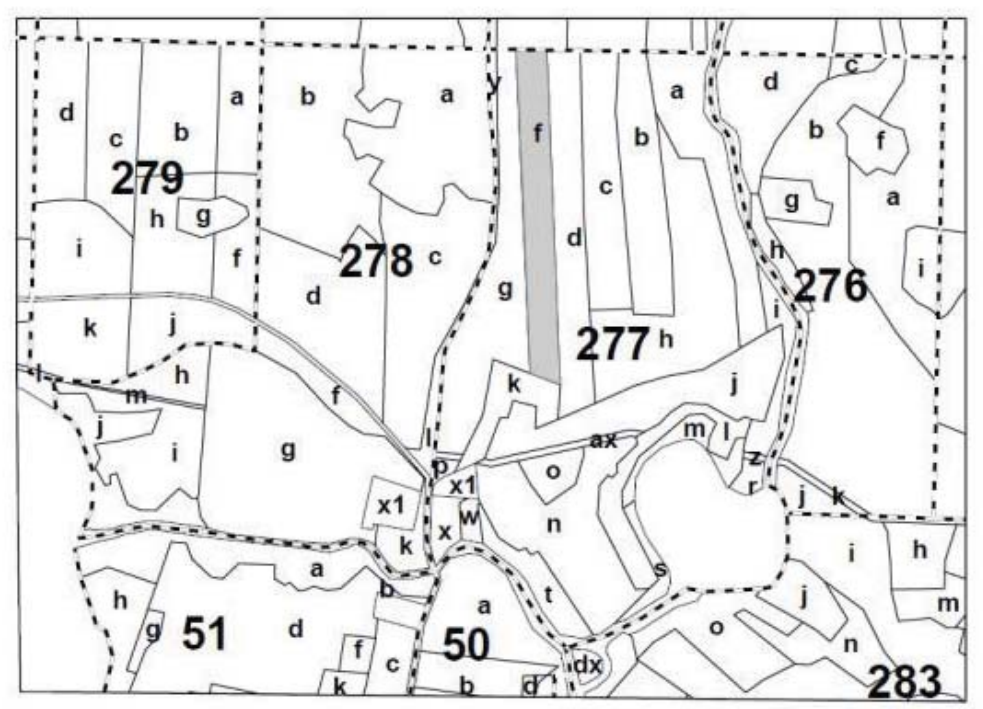

Figure 3. The fragment of inventory maps from 1926 and 2009 with the location of related sites No 44 and 45 and subdivision $277 \mathrm{f}$ 
and deciduous species as well as the total number of species of trees and shrubs observed in the subsequent years. The additional parameters included in the table were the sum of occurrences of coniferous and deciduous species in a given year, and the total number of occurrences of all species.

\subsection{Analysis of changes in the syntaxonomy of phytocoenoses}

Ten relevés (taken and published by Sokołowski, 1965) from 1961 were used in the analysis of changes in the syntaxonomy of plant communities. The second subset consisted of 10 relevés, repeated more or less at the same locations in 2002 by Matuszkiewicz (2007). The third subset consisted of relevés taken by us as part of this study in 2013. The area of relevés was defined on the basis of land description prepared by previous authors, and on the basis of a map covering the area near the village of Laska with marked locations of relevés presented in the study by Sokołowski (1965). Efforts were made to keep the same size of relevés. The method and the cover/abundance scale of Braun-Blanquet (1964) were used for all 30 relevés. The relevés were collated in a phytosociological table based on a chronological sequence of relevés, while the species were first divided into two groups: 1) trees and herbaceous plants, 2) bryophytes and lichens. Species of the second group were further divided into syngenetic groups. The subsequent analyses included all species from the class Vaccinio-Piceetea, while species from other groups were omitted if they occurred in less than three relevés in the table.

Numerical ordination of relevés was performed using a software package CANOCO ver. 5.03 (ter Braak \& Šmilauer, 2012). When preparing the set of relevés for the calculations, the cover-abundance expressed according to Braun-Blanquet's scale was transformed to the scale of Janssen (1975) and van der Maarel (1979). The numerical ordination was carried out using the Principal Component Analysis (PCA). This method was selected after verifying that the gradient length along the first ordination axis was only $2.2 \mathrm{SD}$ (standard deviation), which is consistent with the principles established by ter Braak and Šmilauer (2002). Ellipses showing 95\% confidence intervals for relevés representing each of the three syntaxa were marked on the PCA ordination diagram.

Based on the shifts of three relevés of each time sequences in clouds of points of syntaxonomic units in the ordination diagram drawn in the system of axes I and II, a transition matrix of different types of communities in three development stages was prepared, together with a diagram presenting these transformations.

\subsection{Analysis of modern pollen deposition}

Pollen traps installed at three sites are included into network of Pollen Monitoring Programme (PMP) (Hicks et al., 1996). One trap was placed $800 \mathrm{~m}$ north of the Laska village (palynological site No. 1 in Fig. 1) in more than 100-year old pine forest on the habitat of fresh pine forest, on the southern side of the road running from Laska to Zapceń. Site No. 1 was also described as L-P-F (Laska Pine Forest).

The second trap was installed at the north-western end of the Laska village (site No. 2 in Fig. 1), within the Research Station of Nicolaus Copernicus University. The fresh pine forest adjacent to the village area was characterised by an admixture of deciduous trees - beech and oak growing in small clusters in the understorey and undergrowth. The silver birch and small-leaved lime also occurred, but in the village. This site was denoted as L-PB-F (Laska-Pine and Broad-leaved-Forest).

The third site was located about $1 \mathrm{~km}$ north of the Widno village (site No. 3 in Fig. 1). The pollen trap was placed in the vicinity of the oak-hornbeam forest with some admixture of Pinus sylvestris, $P$. strobus, Betula pendula and Ulmus scabra, which covers the slopes of the Milachowo lake channel. This was the only fragment of the oak-hornbeam forest preserved in the northern part of the Zaborski Landscape Park. A monospecific, more than 100-year-old stand of Fagus sylvatica grows at the NW boundary of this oak-hornbeam patch. The beech was introduced here in the 19th century on the habitat of oak-hornbeam forest, although Sokołowski (1965) classified the forest communities occurring in this area as the Luzulo pilosae-Fagetum. Site No. 3 was denoted as W-B-F (Widno Broad-leaved Forest).

Pollen deposition has been monitored by standard one-year round pollen traps constructed according to Tauber's description (Tauber, 1974; Hicks \& Hyvärinen, 1986). Traps stayed in the ground all year round (OctoberOctober) and their content was treated in a laboratory using standard methods used in pollen analysis (Berglund \& Ralska-Jasiewiczowa, 1986). From 1999 (i.e. after the first year of exposure) until 2013, 15 full annual data sets were obtained only for the site L-PB-F. For various reasons (damage or theft of a trap etc.), the available data sets were smaller at the two remaining sites. The percentage values and pollen accumulation rates (PAR) of individual pollen taxa in a trap, as well as the contribution of deciduous trees and conifers in the AP deposition were calculated for each year. 


\section{Results}

\subsection{Changes of habitat quality}

In the first studied period, i.e. in 1926, the quality of 87 habitats in the study area ranged from class II to V (Fig. 4). Class IV strongly dominated and included 75 sites. The second largest group included 7 sites and was classified within class III. Class V included four sites, and class II only one site. A total of 59 sites preserved the status of class IV from 1926 till 1953, while 15 sites deteriorated from class IV to class III. At seven sites, the quality of habitat deteriorated. One site was moved from class II to class IV, five sites from class III to class IV, and one site from class IV to class V.

In the next two stages, i.e. in 1953 and 1966, most of the sites belonged to habitat quality class IV, i.e. 68 and 64 sites, respectively. In the period of 1953-1966, most of the sites (58) in this class preserved their status, and 7 sites were reclassified from class IV to class III. Thirteen sites remained in class III and one site was reclassified from class V to class IV.

In 2009 , the habitat quality of 87 sites ranged from class I to class III (Fig. 4). Class III comprised the largest number of sites, i.e. 43 sites, and class II -40 sites. Only 4 sites were included in class I.

\subsection{Changes in the undergrowth}

The analysis of the undergrowth revealed a clear increase in the number of species in general and in the number of deciduous species in particular. In 1926, only 2 conifer species occurred in the forest subdivisions where study plots were located. It was the common juniper Juniperus communis recorded in six subdivisions, and the Scots pine Pinus sylvestris recorded in one subdivisions (Table 1).

In 1953, a total of 6 species of trees and shrubs, including two species of conifers and four species of deciduous trees occurred in 87 forest subdivisions. The common juniper was still the most common species, recorded in 13 subdivisions, while the common pine occurred in 9 subdivisions. The deciduous species were most frequently represented by birch Betula pendula, which was recorded in four subdivisions. The hazel Corylus avellana occurred in two subdivisions, and the European beech Fagus sylvatica and the common hornbeam Carpinus betulus were recorded only once. In 1966 and 1976, the common juniper was still the most common species, but also spruce Picea abies occurred in large numbers. The silver birch was still the most common deciduous species. The European beech also began to play an important role. In 1976, the total number of undergrowth species increased to eight.

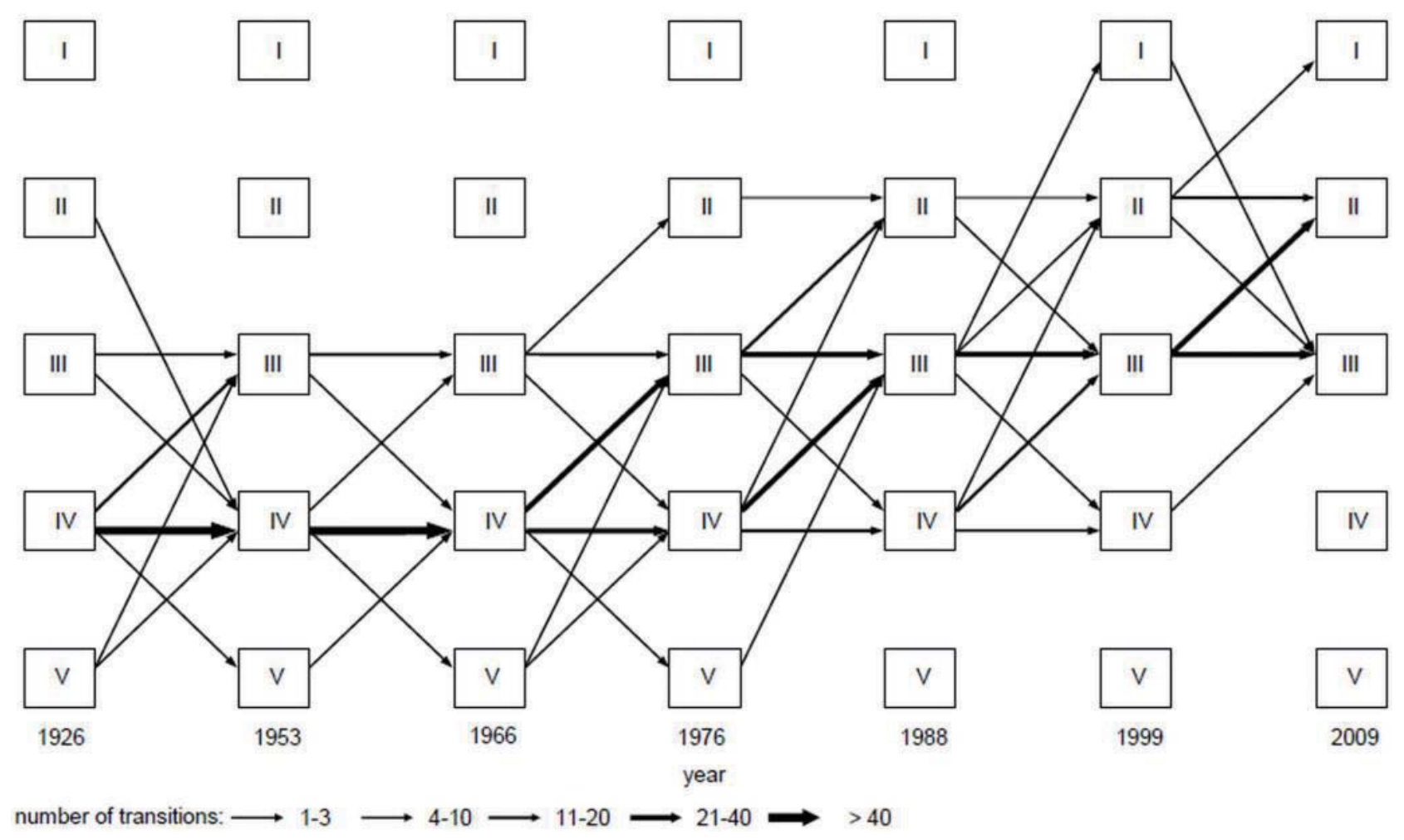

Figure 4. Changes in habitat quality classes $(\mathrm{I}-\mathrm{V})$ of 87 study sites in the sequence of seven inventories 
Table 1. Species composition of understory in 87 forest subdivisions with study sites in seven subsequent inventories

\begin{tabular}{|c|c|c|c|c|c|c|c|}
\hline \multirow{2}{*}{ Species } & \multicolumn{7}{|c|}{ Year } \\
\hline & 1926 & 1953 & 1966 & 1976 & 1988 & 1999 & 2009 \\
\hline Juniperus communis & 6 & 13 & 78 & 59 & 1 & 6 & 9 \\
\hline Picea abies & & & 20 & 19 & 2 & 4 & 6 \\
\hline Sorbus aucuparia & & & & 1 & 4 & 3 & 5 \\
\hline Betula pendula & & 4 & 14 & 7 & & 3 & 5 \\
\hline Pinus sylvestris & 1 & 9 & 5 & 7 & 4 & 9 & 6 \\
\hline Pinus banksiana & & & & & & & 1 \\
\hline Pinus strobus & & & & & & 1 & \\
\hline Fagus sylvatica & & 1 & 4 & 4 & 4 & 7 & 6 \\
\hline Corylus avellana & & 2 & & & 1 & & \\
\hline Frangula alnus & & & & & & & 3 \\
\hline Quercus robur & & & & & & 1 & 2 \\
\hline Carpinus betulus & & 1 & & & & & \\
\hline Padus avium & & & & & & 1 & 1 \\
\hline Populus tremula & & & 1 & & & & \\
\hline Quercus rubra & & & & 1 & & & 1 \\
\hline Acer pseudoplatanus & & & & & & & 1 \\
\hline Acer platanoides & & & & & 1 & & \\
\hline Salix alba & & & & & & & 1 \\
\hline Padus serotina & & & & 1 & & & \\
\hline \multicolumn{8}{|l|}{ Number of species } \\
\hline coniferous & 2 & 2 & 3 & 3 & 3 & 4 & 4 \\
\hline deciduous & & 4 & 3 & 5 & 4 & 5 & 9 \\
\hline total & 2 & 6 & 6 & 8 & 7 & 9 & 13 \\
\hline \multicolumn{8}{|l|}{ Sum of species occurrences } \\
\hline coniferous & 7 & 22 & 103 & 85 & 7 & 20 & 22 \\
\hline deciduous & & 8 & 19 & 14 & 10 & 15 & 25 \\
\hline total & 7 & 30 & 122 & 99 & 17 & 35 & 47 \\
\hline
\end{tabular}

In the next three phases, i.e. in 1988, 1999 and 2009, the number of species was 7,9 and 13 , respectively. The number of coniferous decreased, while the number of deciduous species increased. The European beech was the most common deciduous species (4, 7 and 6, respectively in 1988, 1999 and 2009). Also silver birch and rowan Sorbus aucuparia occurred frequently.

When analyzing Table 1, which contains also the total number of occurrences of deciduous and conifer trees, and the total number of occurrences of all undergrowth species, 
it appears that especially in 1988 and 2009, deciduous species dominated over conifer species. Their number during those years was 10 and 25 in relation to 7 and 22 of conifers, and their percentage was $58.82 \%$ and $53.19 \%$, respectively. This was a significant increase compared to 1926 when deciduous species did not occur in the undergrowth.

\subsection{Changes in the syntaxonomy of phytocoenoses}

Relevés taken by Sokołowski (1965) in 1961 were included by the author in the following three syntaxa: Vaccinio myrtilli-Pinetum cladonietosum, Vaccinio myrtilli-Pinetum typicum var. cladonietosum and Vaccinio myrtilliPinetum typicum var. typicum. According to more recent classification of Polish plant communities proposed by
W. Matuszkiewicz (2007), the following syntaxa correspond to the above units: Cladonio-Pinetum, LeucobryoPinetum cladonietosum and Leucobryo-Pinetum typicum. These three units are clearly distinguished in the PCA ordination diagram (Fig. 5).

Two syntaxa, most different from each other in terms of habitat quality, are marked with symbols CP and LPt or LPtFs. Relevés of the former syntaxon, i.e. CladonioPinetum, take the outermost positions on the left side of the ordination diagram, corresponding to low values of axis I. Relevés of the latter syntaxons, i.e. Leucobryo-Pinetum typicum or Leucobryo-Pinetum typicum with Fagus sylvatica in the forest overstory, are located on the opposite side of the diagram (Fig. 5). In the middle of the diagram, there are relevés marked with the symbol LPc corresponding to

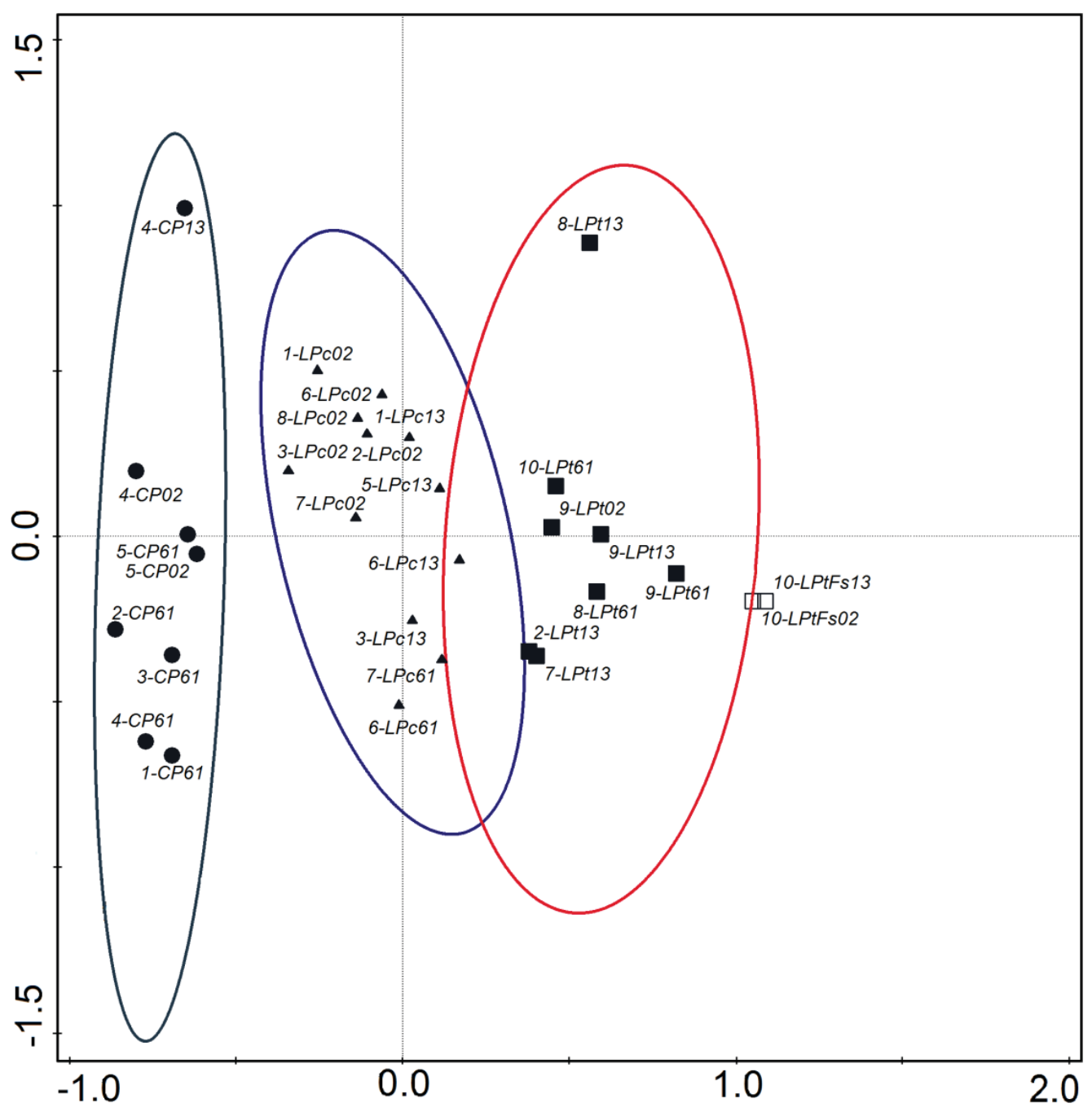

Figure 5. PCA ordination diagram of 30 relevés taken in 10 of the same or close study sites in the vegetation seasons of 1961,2002 and 2013 (CP - Cladonio-Pinetum; LPc - Leucobryo-Pinetum cladonietosum; LPt - Leucobryo-Pinetum typicum; LPtFs Leucobryo-Pinetum with Fagus sylvatica in the forest overstory; numbers 1-10, and 61, 02, 13 indicate successive numbers of time sequences including 1961, 2002, 2013) 
Leucobryo-Pinetum cladonietosum. The ellipse representing the $95 \%$ confidence interval of this syntaxon partly overlaps with the ellipse of Leucobryo-Pinetum typicum, which proves a high similarity of relevés from both subsets. Two relevés made in communities of fresh (mesic) pine forest, where Fagus sylvatica reaches the upper tree layer, take the outermost position on the right-hand side of the ordination diagram, just outside the ellipse representing the $95 \%$ confidence interval of the Leucobryo-Pinetum typicum association (Fig. 5).

In the subset $\mathrm{CP}$, only relevés from one time series (4CP) preserved characteristics of the association CladonioPinetum in all three states. The two other relevés in this subset, i.e. 1-CP61 and 3-CP61, were moved to class LPc in 2002, and stay in this class in 2013. Relevé 2-CP61 was moved to class LPc in 2002 and to LPt in 2013. The last relevé of this group, i.e. 5-CP61 was classified to the same syntaxon in 2002 but in 2013 - to the syntaxon LPc.

In the subset LPc, the relevés of time series 6-LPc preserved characteristics of Leucobryo-Pinetum cladonietosum in 2002 and 2013. Relevé 7-LPc61 preserved its characteristics in 2002 and was moved to the syntaxon LPt in 2013.

Only one relevé 8-LPt was classified in 2002 to LPc, and in 2013 again to the syntaxon LPt. Relevé 9 from 1961 included in the syntaxon LPt preserved the characteristics over the next years. Relevé 10-LPt61 was moved to the class LPtFs in 2002 and 2013.

The number of transitions between syntaxa is presented in Figure 6. It appears that the largest number of

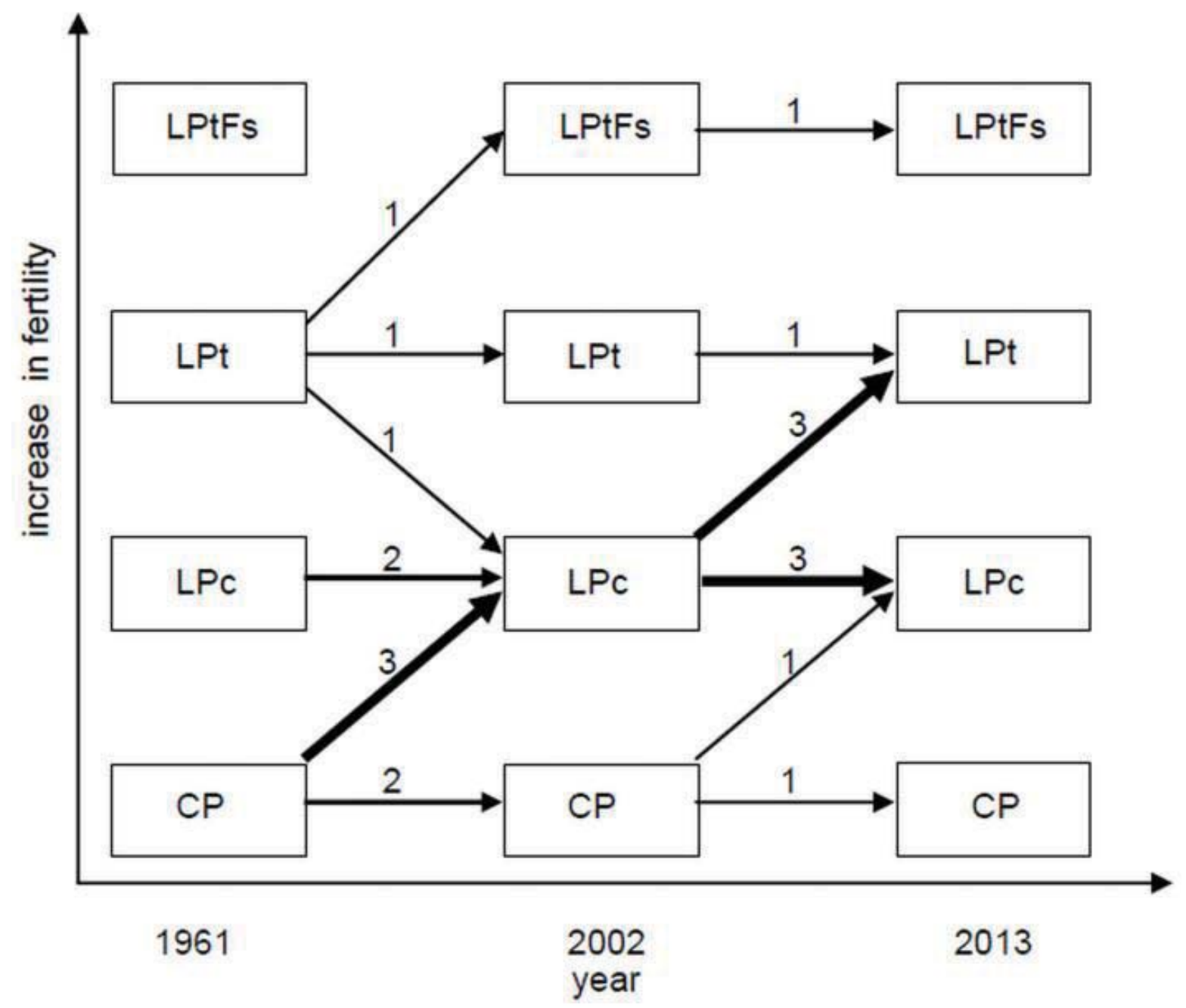

Figure 6. Changes in the syntaxonomic status of 30 relevés taken at 10 study sites in 1961, 2002 and 2013 (explanations of letter symbols as in Fig. 4, numbers above arrows denote number of transitions) 
transitions (three) was from CP to LPc, and from LPc to LPt. These transitions occurred between 1961 and 2002, and 2002 and 2013, respectively.

The phytosociological synoptic table containing 30 relevés shows that the transition from Cladonio-Pinetum to Leucobryo-Pinetum is characterized by a reduction of lichens in phytocenoses, loss of species dependent on former cattle and sheep grazing in the forest, such as Festuca ovina and Carex ericetorum, and an increase in the number of species characteristic of the association LeucobryoPinetum, such as Vaccinium myrtillus, V. vitis-idaea and Pleurozium schreberi. Transformations within the association Leucobryo-Pinetum are reflected in the loss of species such as Melandrium album and Luzula pilosa, and in the increase in the number of species of trees and shrubs, especially deciduous ones, like beech, birch, oak and common rowan. Recently, invasive alien species has also occurred, e.g. Padus serotina.

The full structure and species composition of 30 relevés are presented in Table 2. Only three relevés: 5-CP61, 8-LPc02 and 10-LPtFs13 were classified by Matuszkiewicz (2007) into slightly different syntaxa compared to those in Table 2 based on the results of numerical ordination. According to the classification carried out by Matuszkiewicz (2007) using the standard phytosociological method, these relevés would have symbols 5-LPc61, 8-LPt02 and 10-LPt02, respectively.

In the ordination diagram, most of the relevés in 2002 moved to the top of the diagram (towards higher values on axis II) in relation to their position in 1961 (Fig. 5). It appears from the analysis of the structure of relevés in the synoptic table that the factor differentiating the relevés from these two periods are differences in the complexity of tree layers due age of forest stands. Relevés from 2002 were taken in forest stands consisting of layers $a$ and $b$ (i.e. overstorey and understorey), and the undergrowth of the same tree species in the ground layer c. In the case of relevés $4-\mathrm{CP}$ and $8-\mathrm{LPt}$, this trend was observed also in 2013. Other relevés, after reaching high values on axis II in 2002, usually showed a decrease in 2013. The smaller number of forest layers with the same tree species observed in the next period, shows that the age of the forest stand became more homogenous in 2013.

The varied age of Fagus sylvatica trees, especially the presence of juvenile specimens, clearly observed in relevés of time sequence No. 10 in Figure 5 and Table 2, indicates that beech (which requires more fertile soil in generally higher habitat quality classes compared to pine) has good conditions for its growth.

\subsection{Modern pollen deposition in different types of forest}

Based on the analysis of the species composition of the pollen samples in relation to the data on vegetation changes in Pomerania provided in the ecological literature, we have determined that the increase in the habitat quality in the study area is best reflected in the presence of Carpinus, Quercus and Fagus pollen and in the total amount of pollen of broadleaf trees. Therefore, mainly these parameters are presented in the chapter 3.4. In addition to the three above-mentioned taxa, also Alnus and Betula pollen have a significant contribution in the analyzed spectra. Alder, however, occurs in river valleys and the analysis included the vegetation occurring on the plateau. Betula pollen was frequently present in the pioneer succession stages of the forest reconstruction process. Nevertheless, the contribution of this species in the forest communities on the plateau did not indicate an increase in the quality of habitats. Other taxa of deciduous trees were represented by pollen of Tilia, Corylus, Ulmus, Fraxinus, Acer, Populus, Sorbus, Ribes, Salix and Viscum, and conifers - by Pinus sylvestris, Picea, Larix and Juniperus.

As evidenced by the performed analysis, there were significant differences in the values of the pollen accumulation rate (PAR) for the three main deciduous taxa at the study sites. At the site L-P-F in 1999-2003, PAR values of these taxa were low. The highest values of Quercus PAR were recorded in 1999 and Carpinus betulus in 2001 (Fig. 7). The Fagus pollen accumulation rate was small, i.e. only 21 pollen grains $\mathrm{cm}^{-2}$ year-1 in 2000 .

At the site W-B-F, deposition of pollen of these trees was several times higher. Especially Carpinus PAR was high in 2002, up to 2,900 pollen grains $\mathrm{cm}^{-2}$ year $^{-1}$. The Quercus pollen accumulation rate was 1,500 in 2003, while Fagus PAR exceeded 700 pollen grains $\mathrm{cm}^{-2}$ year ${ }^{-1}$ in 2002 (Fig. 7).

In the pollen trap L-PB-F in the same period, i.e. in 1999-2003, pollen deposition of the three deciduous taxa was small, usually less than in the trap L-P-F (Fig. 8). In the next years, the pollen accumulation rate significantly increased and exceeded the values obtained in 1999-2003 for the site L-P-F. The Carpinus pollen accumulation rate exceeded 400 grains $\mathrm{cm}^{-2}$ year $^{-1}$ in 2007 and 2011, and 300 grains $\mathrm{cm}^{-2}$ year-1 in 2013. The Quercus pollen accumulation rate was up to 900 grains $\mathrm{cm}^{-2}$ year $^{-1}$ in 2007 and 600 in 2005-2006, and over 500 grains cm$^{-2}$ year $^{-1}$ in 2010. Fagus PAR was above 500 grains $\mathrm{cm}^{-2}$ year-1 in 2006 and 400 grains $\mathrm{cm}^{-2}$ year ${ }^{-1}$. 


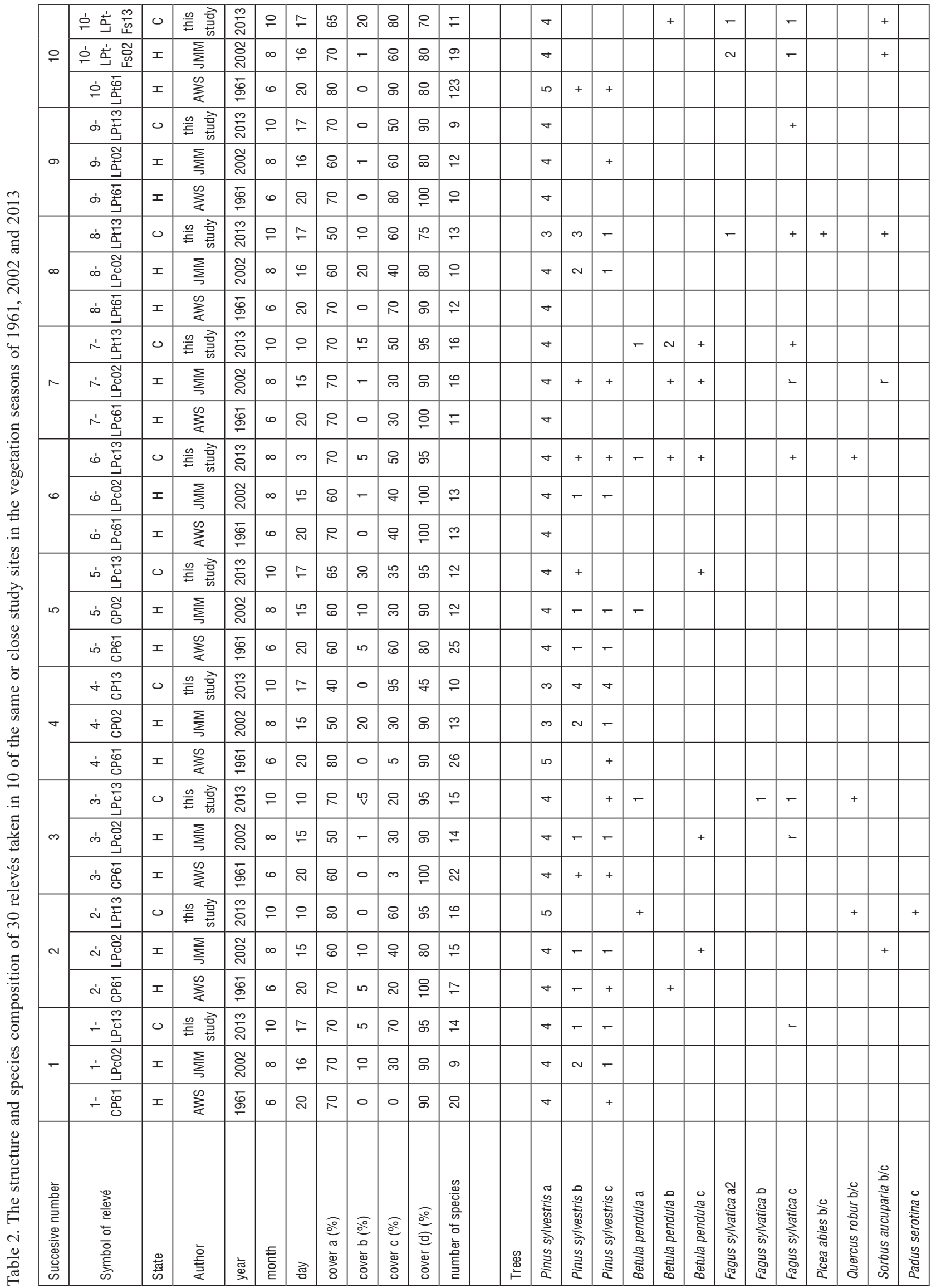




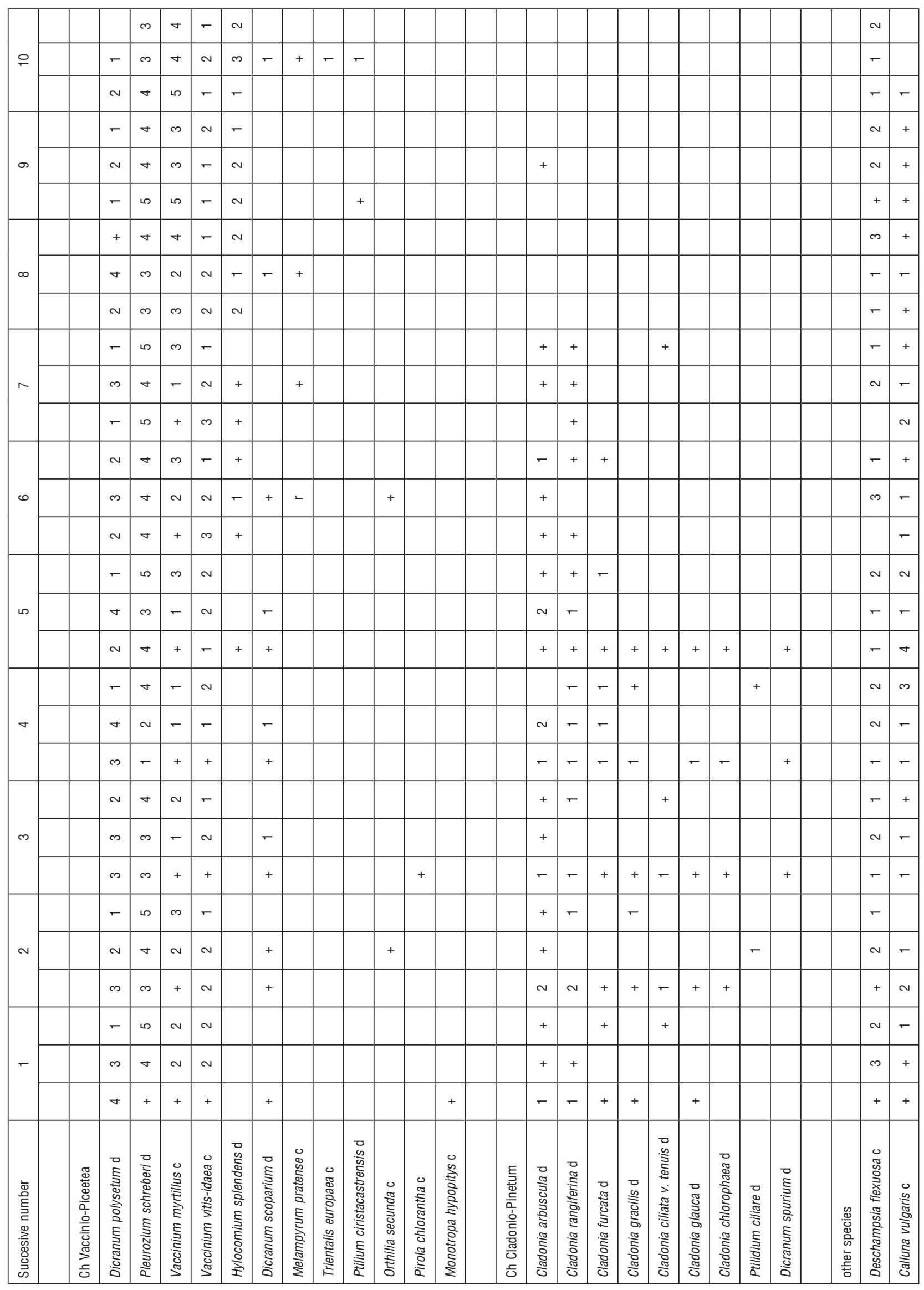




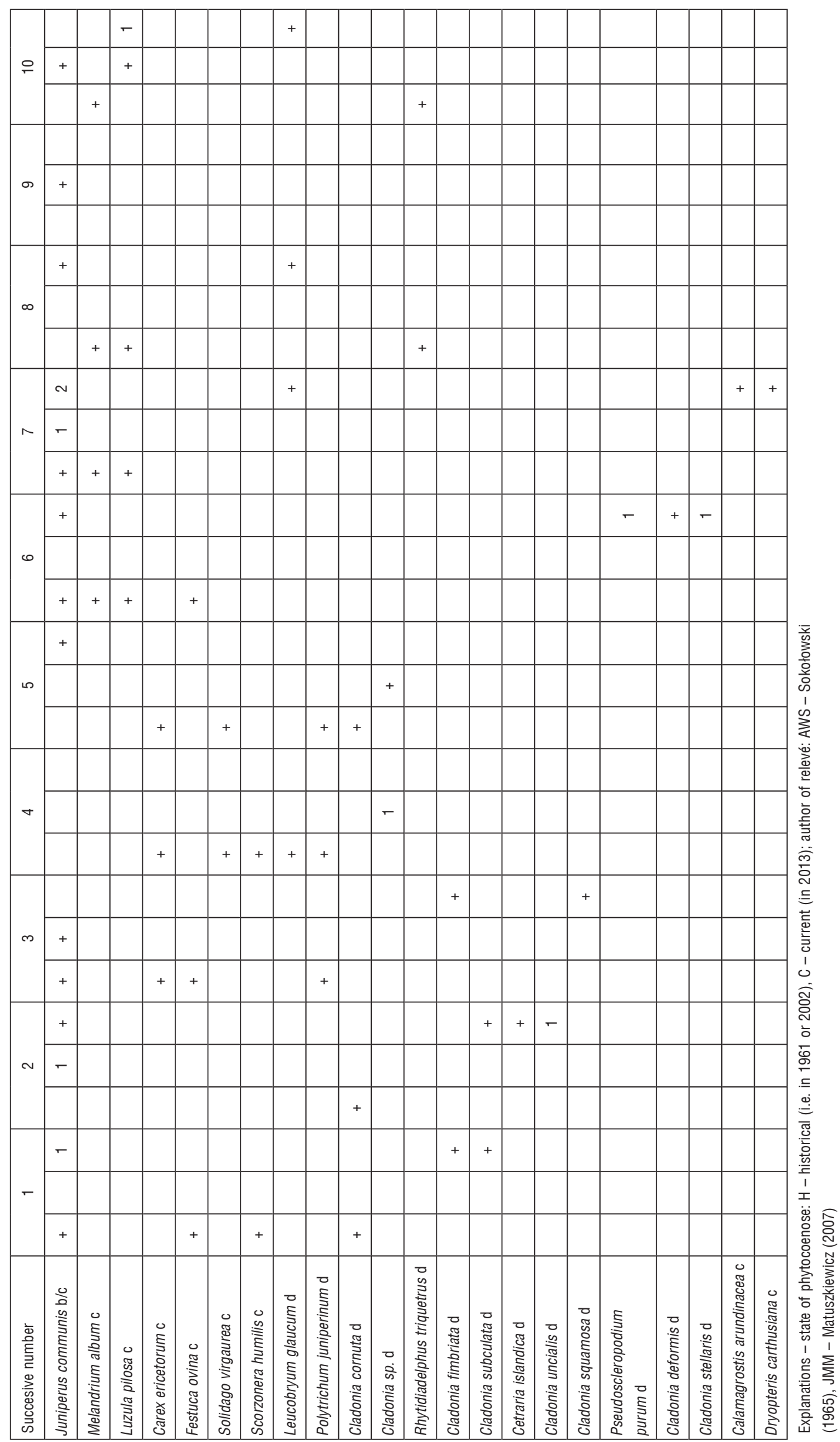




\section{Carpinus}
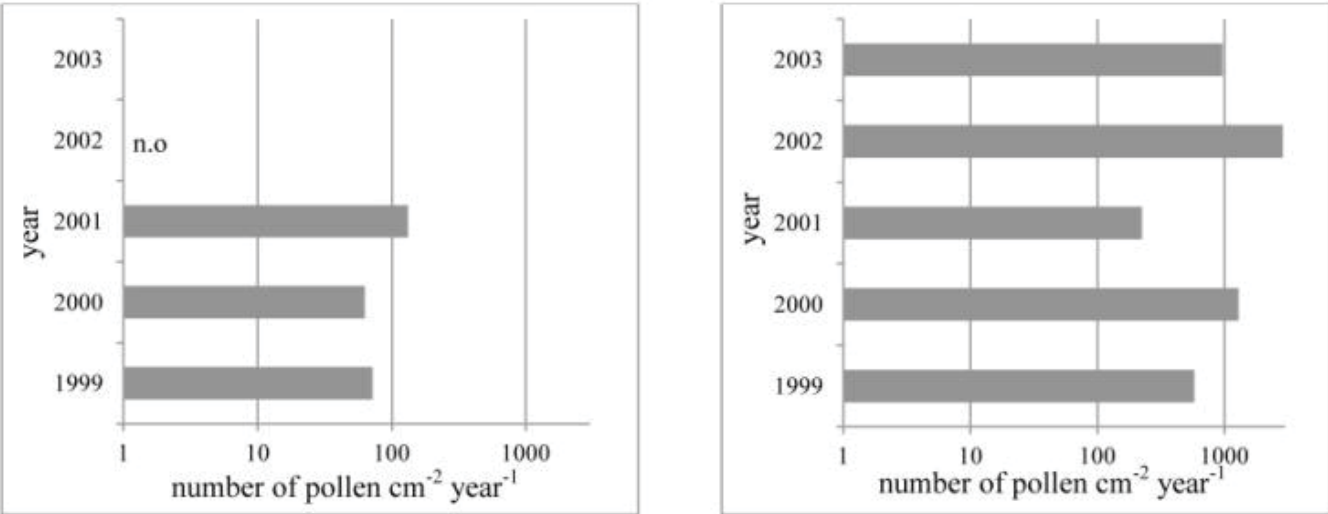

\section{Quercus}
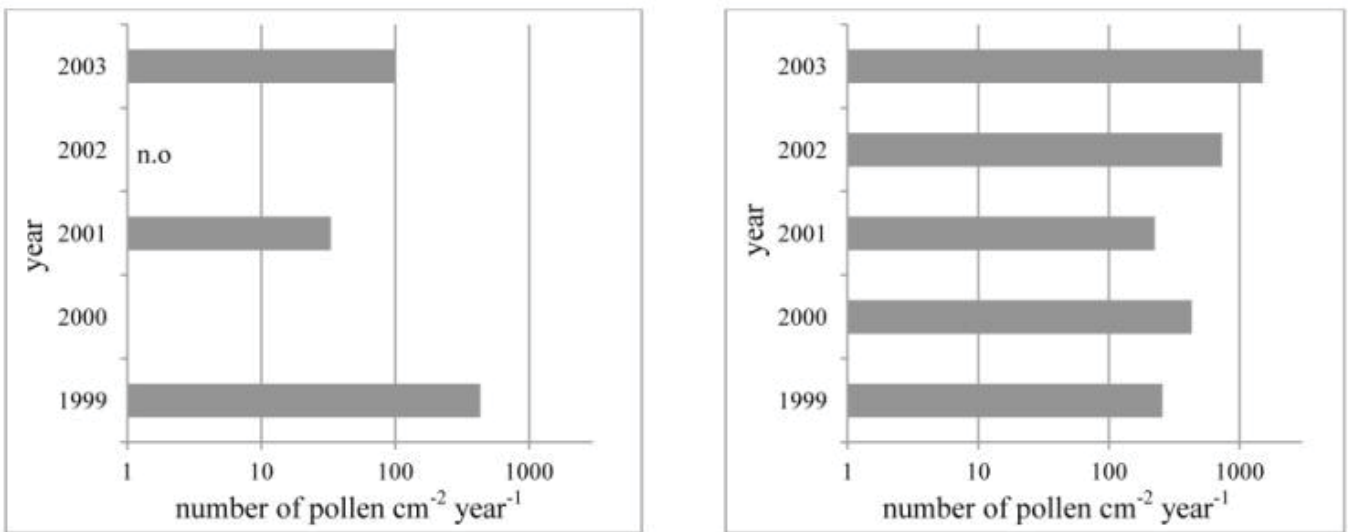

\section{Fagus}
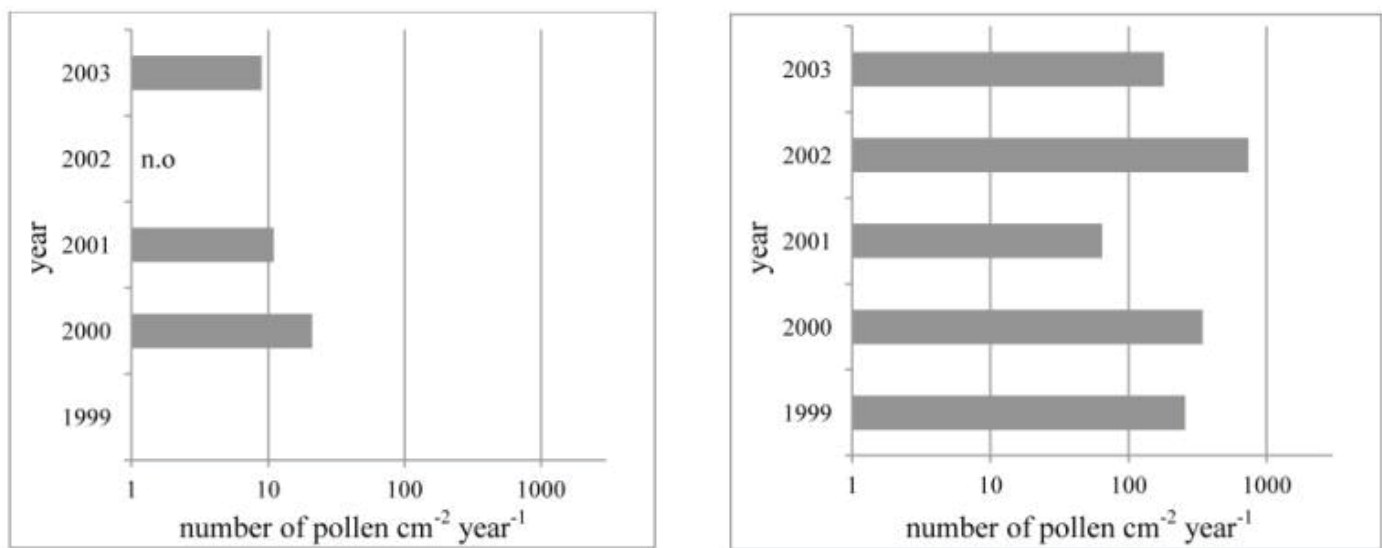

Figure 7. Annual pollen deposition at the sites L-P-F (Laska, pine forest) and W-B-F (Widno, broad-leaved forest) in 1999-2003. Abbreviation n.o stands for: no observations were made at the pollen site during the year of observation; other dates without abbreviations and histograms denote that sporomorphs of tree species were not recorded in the pollen sample 


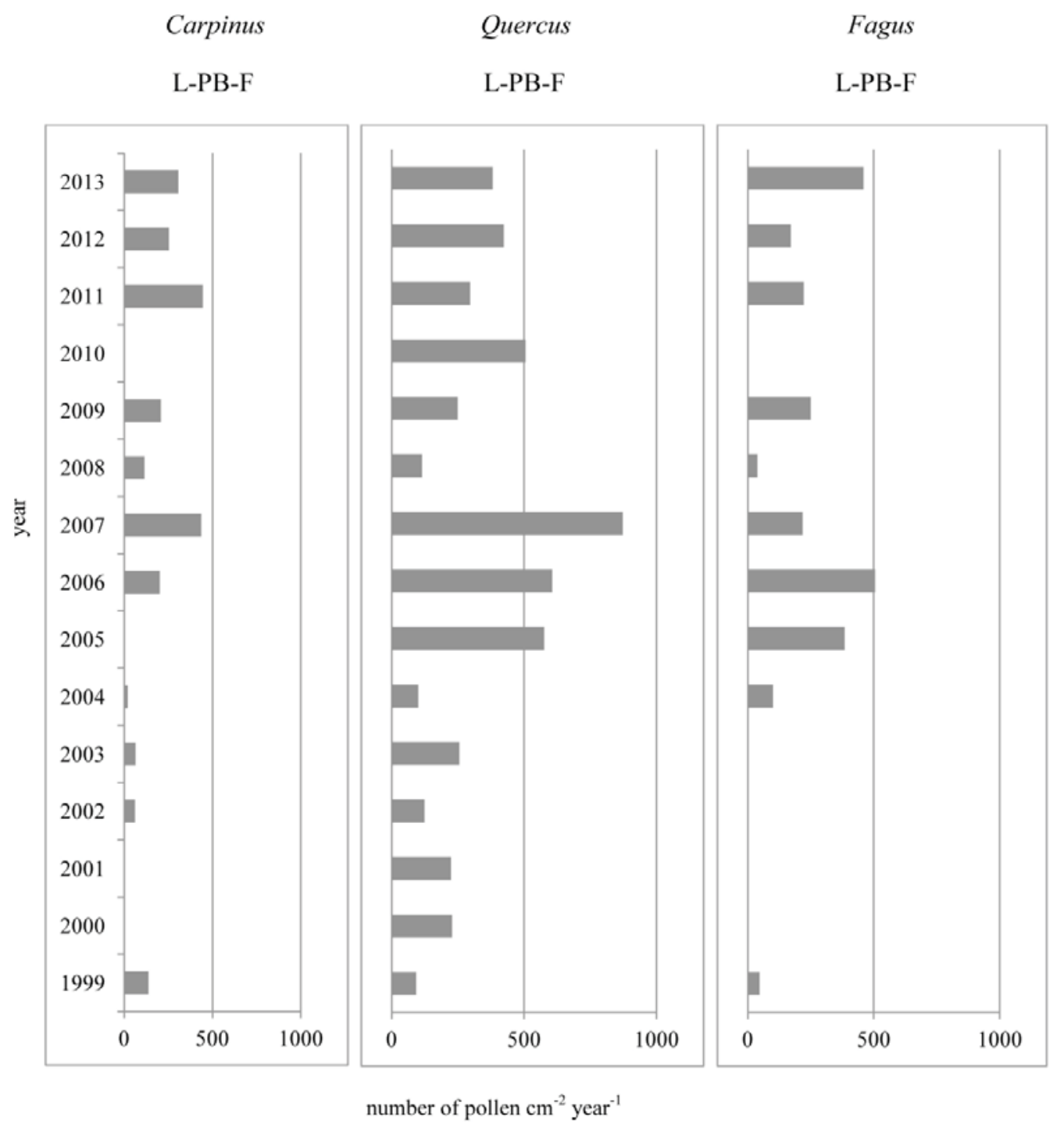

Figure 8. Present-day pollen deposition at the site L-PB-F (Laska, pine forest with broad-leaved trees) in 1999-2013. Dates without histograms denote that sporomorphs of tree species were not recorded in the pollen sample

In 1999-2003, most of the pollen of deciduous trees and shrubs occurred in the trap W-B-F or L-PB-F (Fig. 9). The lowest percentage of deciduous pollen was recorded at the site L-P-F. In the next years of pollen rain monitoring at the site L-PB-F, the percentage of deciduous pollen was increasing, reaching the maximum values in 2007 and 2006, 70.4\% and 76.6\%, respectively. At the site L-PB-F, the lowest value $(11.1 \%)$ of this parameter was noted in 2002. It is not known whether the parameter was even lower at the site L-P-F in this year, because monitoring was not carried out at that site in 2002.

In recent years, the contribution of pollen of deciduous taxa has decreased at the site L-PB-F. Low values were observed especially in 2005, 2009 and 2013, i.e. only slightly above $20 \%$. However, the value had never been lower than
$11.1 \%$, which was recorded at this site in 2002 (Fig. 9). The lowest values of this parameter resulted from the high contribution of pine pollen.

\section{Discussion}

\subsection{Possible reasons of changes in the habitat}

The studies carried out at 87 sites confirmed that the habitat quality increased mostly from IV to class II (on average at all the study sites - from III.9 in 1926 to II.4 in 2009). According to the inventory book for 2009, the entire Przymuszewo Forest Division (over 18,500 hectares) was characterised by the average quality of III. The difference 
between the mean values for the set of sites and for all forest subdivisions probably results from the fact that the sites in the early 1920 s were established in healthy-looking stands growing on fertile habitats rather than in other areas of the forest division. For this reason, the processes of transformations of dry pine forests into fresh pine forests and then into mixed forests proceeded faster at the sites than outside the sites.
A similar increase in the habitat quality was described by Brzeziecki (1999) in the forest division of Włocławek located in central Poland, as well in the Białowieża Primeval Forest in north-western Poland. According to the aforementioned author, there are three possible causes of this phenomenon. The first explanation is the climate change. According to the author, the climate warming causes changes in the species composition of forest stands, which

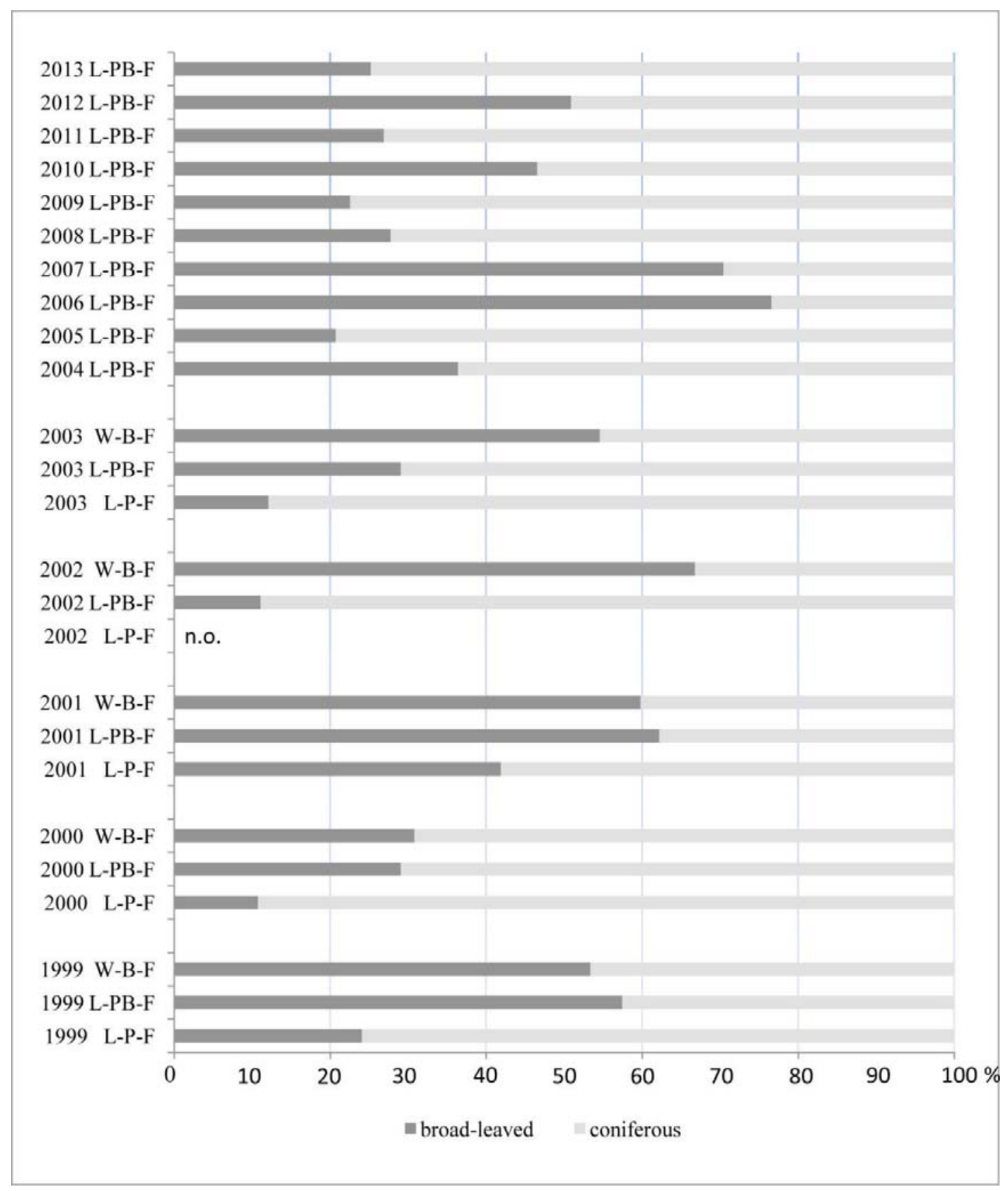

Figure 9. Contribution of pollen grains of broad-leaved and coniferous trees and shrubs in annual pollen deposition at three sites in 1999-2013. Abbreviation n.o stands for: no observations were made at the pollen site during the year of observation 
entail changes in the soil and habitat. Milder climate is conducive to the development of deciduous species. This hypothesis is confirmed by observations of forest succession in different regions of Poland (Kowalski, 1992).

The second cause is related to the concept of regeneration. The Scots pine introduced more than 200 years ago caused deterioration of the habitat, which is directly related to the soil acidification caused by the decomposition of conifer litter and the accompanying shrubs. These components of a forest community contribute most to the acidification of soil (Puchalski \& Prusinkiewicz, 1975). After years of monocultures and changes in the forest management type towards the pro-ecological one, the regeneration occurs which is manifested by an increased contribution of deciduous species. This process is described (Matuszkiewicz, 2007) in the reserve of Bukowa Góra near Kartuzy where regeneration of the association Fago-Quercetum followed after the association of acidophilous beech forest Luzulo pilosae-Fagetum. Forest communities representing the association Luzulo pilosae-Fagetum could also result from the elimination of hornbeam and admixture species, as well as from the reduction of oak in the oak-hornbeam forests (Olaczek, 1990). This would indicate that beech forests are substitute communities, and the recently observed expansion of hornbeam in beech forests reflects the regeneration of oak-hornbeam communities.

The third cause is a human factor that may be related to errors made in the classification of habitats (Brzeziecki, 1999). The analysis covered a period of over 80 years and during this period the rules and instructions according to which the classification was performed were changed. Significant changes in this regard took place in the mid1960 s, e.g. a more accurate fertility grading scale was introduced based on half-degrees: I.5, II.5, etc. To standardize the assessment throughout the whole study period from 1926 to 2013, such degrees have been reduced in this work to class I and class II, respectively. On the other hand, the more accurate scale may have advanced the observed changes.

Furthermore an increase in the fertility of forest habitats occurs also as a result of chemical emissions into the atmosphere, especially from industry and municipal services (Sokołowski, 1993). This factor increases the eutrophication of forest habitats, which according to the abovementioned author are reflected in the changes of species composition in large areas of Poland.

\subsection{Influence of natural processes and silvicultural treatments on the structure of tree stands and syntaxonomic position of phytocoenoses}

Forest stands which were included in the assessment of the habitat quality were most often in age class III and IV, i.e. they were over 40 or 60 years old.
The process of afforestation of heathlands, implemented in the study area 165 years ago, has followed the scenario specified by other authors for the forests planted on heathlands. For example, pine dominated in the first 100 years in the forest planted on heathlands in Lüneburger Heide, while Quercus dominated in the next 200 years, and Fagus sylvatica dominated in the following phase (Lauschner \& Rode, 1999). Perhaps the observed increase in the proportion of beech and oak in the Forest District Przymuszewo, is the beginning of a phase with the dominance of deciduous tree species. In Germany, on the Lüneburg Heide, such processes were described (Rode 1999a, b; von Oheimb, 2008). In three stages of forest succession on former heathlands, i.e. Calluna heathland, a pioneer birchpine woodland and a terminal oak-beech forest, Scots pine has the highest intake of water and nutrients (Rode, 1999a). The successional development of forest on former heathlands was associated with the increased productivity and significant enrichment of organic material and nutrients in the organic layer, whereas the nutrient storage in the mineral soil did not change (Rode, 1999b).

Not only the land use before the afforestation, but also the type of ownership and the related method of forest use after changes in the land cover significantly affected the structure of the present-day vegetation in our study area. In the past, the studied forests belonged to the Prussian state and later to the Polish state as a state forest, as well as to private owners. Cattle and sheep grazing was implemented mostly in the forests of the latter group. Consequently, the species like Festuca ovina, Carex ericetorum and others occurred in the forests of the early 1960s (Sokołowski, 1965).

The second silvicultural treatment which affected the later structure of phytocoenoses consisted in the introduction of undergrowth. Forests on better habitats, often representing forms of nature protection where undergrowth was not required (Brzeziecki, 1999).

The conducted analysis showed that in the 1920s, the undergrowth did not occur in the local forests, so it was also absent at 87 study sites. The undergrowth has been introduced on a larger scale since the 1970s. Research in Forest Division of Rytel, adjacent to Przymuszewo (Hajder, 2005), also demonstrated an increase in the contribution of undergrowth in the forest structure. The undergrowth, especially beech, was introduced based on the hypothesis that beech is a host of pine (Tuszyński \& Gorzelak, 1998).

\subsection{Possible causes of spatial and temporal changes in the modern pollen deposition}

The increase in the percentage of broadleaved species in the main tree stand and in the undergrowth was followed by an increase in the contribution of deciduous tree pollen in the modern pollen spectra. Pollen deposition has 
been monitored since 1999. of individual pollen taxa shows significant differences in subsequent years. This is affected both by the diversity of meteorological factors, as well as, by biological properties, especially the amount of pollen produced by various species of trees in different years. Different species of trees, including the deciduous ones, bloom with varying intensity and produce different amounts of pollen in different years. Beech starts flowering at the age of 40-50 years in open areas and at the age of 60-80 years in a dense forest stand (Bradshaw et al., 2010). The beech flowers abundantly every few years and its pollen season usually lasts about two weeks (Latałowa et al., 2004). This species is one of the most copious pollen producers, however, its poor dispersal ability and rapid fall of pollen grains results in beech being under-represented in pollen assemblages (Sugita et al., 1999). The interpretation of isopollen maps based on the assumption that $2 \%$ beech pollen values indicate its local, scattered presence in vegetation communities, whereas values of $5 \%$ indicate the occurrence of beech-dominated forests on a regional scale (Huntley \& Birks, 1983). However much lower Fagus pollen values to interpret beech distribution were used (Björkman, 1996), following field observations (Woods \& Davis, 1989). These authors accept a likely presence of the first beech stands at the value of $0.5 \%$ in regional pollen diagrams, and a certain presence of beech stands on a local scale when pollen values are $0.5-1 \%$, whereas the regional expansion would be indicated by values of $2-5 \%$. In contrast, the results of long-term annual pollen monitoring, carried out in northern Poland, showed that values ranging from 0.1 to $0.6 \%$ may indicate the presence of beech in tree stands and its possible slow migration to a new area (Pidek et al., 2009). In our samples from pollen traps L-P-F, L-PB-F and W-B-F, the contribution of Fagus sylvatica pollen in the current deposition (AP + NAP) was on average $0.09,0.36$ and $0.67 \%$, with the maximum values of 0.16 (in 2000), 1.09 (in 2013) and 1.32\% (in 2002), respectively. Thus, mean values of the beech pollen contribution from the traps L-PB-F and W-B-F were within the above range. These values slightly exceeded the upper limit of the local representativeness for fossil samples (Björkman, 1996).

Our results can also be compared with another data (Poska \& Pidek, 2010). The authors concluded that in the Roztocze region in SE Poland, the regional signal is represented by the mean pollen accumulation rate $<500$ grains $\mathrm{cm}^{-2}$ year ${ }^{-1}$, and the local presence/absence threshold values for Fagus sylvatica is $>2,000$ grains $\mathrm{cm}^{-2}$ year $^{-1}$. In our pollen sample L-PB-F from the area where a clear increase in Fagus sylvatica in the tree stands was observed, the proportion of pollen grains reached the upper level of the regional signal. In the sample from the site W-B-F located in oak-hornbeam forest adjacent to the beech trees by Lake Milachowo, the contribution of beech pollen was almost twice as high as the limit for the regional representative- ness. In 2002, i.e. in the year with the highest proportion of Fagus sylvatica pollen at this site, the amount of pollen of this species was, however, twice as low as the limit value corresponding to the local representativeness (Poska \& Pidek, 2010).

The $1 \%$ content of Carpinus betulus pollen in the fossil sample indicates the presence of scattered sites of the species in the landscape, $5 \%$ indicates the important role of this species in the forest stand and 10\% Carpinus indicates the local dominance of this species in the forest communities (Huntley \& Birks, 1983). The same authors reported also that the content of $2 \%$ of the Quercus pollen indicates the local occurrence of oaks. In our analyses, the contribution of Carpinus pollen exceeded $1 \%$ of the annual pollen rain, but only once at the site L-P-F (1.18\% in 2001) and L-PB-F (1.26\% in 2007). In oak-hornbeam forest and the adjacent beech forest, the percentage of hornbeam pollen exceeded once $5 \%(5.18 \%$ in 2002$)$ at the site W-B-F. In the remaining five years of observations, the percentage of hornbeam pollen ranged from 0.8 to $3.5 \%$. A value below $1 \%$ occurred only once $(0.8 \%$ in 2001$)$.

The percentage of Quercus pollen in the annual pollen rain exceeded once the value of $2 \%$ at the site L-PB-F (2.53\% in 2007) and W-B-F (4.27\% in 2003). In the fresh pine forest (L-P-F), the maximum contribution of oak pollen in the annual pollen rain was only $1.15 \%$ in 1999 . Factors such as the structure of pollen grains and the degree of landscape openness, and different canopies of trees may also affect the spread of pollen along different distances. Moreover, our previous numerical classifications of modern pollen spectra (Filbrandt-Czaja et al., 2012) showed that canopy of trees may increase the differences between the pollen spectra from the forest sites. The differences are larger than between pollen samples from an open landscape. Such an effect was possible to notice despite the fact that in our highly afforested area, the dominance of pine in the regional pollen rain decreased the diversity of palynological data.

Carpinus betulus pollen occurred in the pollen spectra of all three sites, but we assumed that the hornbeam grows only at the site W-B-F where oak-hornbeam forest GalioCarpinetum occurs and acidophilous beech forest Luzulo pilosae-Fagetum in its vicinity. These sites are located just over $1 \mathrm{~km}$ from each other. In the forest landscape, Carpinus pollen is transported at a distance of $1 \mathrm{~km}$ (Jackson, 1990; Sugita, 1998). In this work, when studying the relation between the pollen rain and the type of afforestation, we have considered a vegetation cover within a radius of $1 \mathrm{~km}$ around a sampling site. We decided that the area of a circle with a radius of $1 \mathrm{~km}$ is the right size for the source area of pollen coming from the local environs - relevant source area of pollen - RSAP which is a distance beyond which there is no correlation between the pollen deposited at a given site and the surrounding vegetation (Sugita, 
1994). In the pollen spectrum from the site L-PB-F with the longest time sequence, an increase in the contribution of Carpinus pollen has been observed in recent years. The reason for this increase may be a recent progressive increase in the contribution of Carpinus betulus in the beech stand (Olaczek, 1990), is a manifestation of oak-hornbeam forest regeneration on habitats of this type of forests, where oak and hornbeam were eliminated in the past from the tree layer, which consequently led to a strong dominance of Fagus sylvatica.

\section{Conclusions}

Our observations have revealed that mostly three parameters, i.e. an indicator of habitat quality determined based on the height of pine of a specific age, the undergrowth species composition described by the total number of species and the contribution of deciduous species, and a syntaxonomic status of a phytocoenosis, are good predictors of changes in the habitat fertility, which well express the directions of changes in the structure of forests reconstructed on heaths. Both the forces of nature and silvicultural methods applied by foresters significantly contribute to the increase in the habitat fertility and the process of structural changes in forest phytocoenoses. These beneficial treatments include the introduction of undergrowth, the increasing contribution of deciduous species in the reconstruction of forests, and recently also the creation of storage reservoirs in forests, which result in raising the groundwater level and air humidity, and consequently positively affects the growth of deciduous components in the tree layer. The importance of applied treatments has not yet been sufficiently recognized in the quest to answer the question whether an increase in the fertility of forest habitats is a real phenomenon.

Among four analysed parameters, the structure of annual pollen rain is the least explicit in expressing the direction of changes occurring at present in the vegetation. This is because a pollen spectrum is determined by many factors, i.e. biological, environmental and silvicultural ones. More specifically, these factors include in particular four phenomena observed in the study area: 1 - many of the deciduous trees are young specimens, occurring only in the understory, which have not yet reached the flowering phase, 2 - there is a large variability in meteorological factors in subsequent growing seasons, which influence on pollen production, 3 - there are differences in blossoming between species in subsequent years (biological rhythm), 4 - there is a strong dominance of pine in local pollen and pollen coming from a distant transport.

Not without impact on the lesser expression of the analysed changes is also the shorter duration of the research focused on the structure of modern pollen deposition compared to the research focused on changes in the quality of habitat, the species structure of understory and syntaxonomic affinity of phytocoenoses. Therefore, palynological studies are continued and expanded by our team. They should show whether species diversity of AP and the contribution of deciduous arboreal pollen will be higher in the future.

\section{Acknowledgments}

We thank the head of the Przymuszewo Forest District for giving consent to conduct research and making available historical data of the Forest District.

This work was funded by State Committee for Scientific Research (no. 3P06L 008 25) "Past and present diversity of the landscape of Tuchola Forest in the light of pollen, phytosociological and satellite analysis" and the research grant by Ministry of Science and Higher Education (no. N N305 336834) "Current and potential resources of organic carbon in the landscape of Tuchola Forest".

\section{References}

Amici V., Rocchini D., Geri F., Bacaro G., Marcantonio M. \& Chiarucci A., 2012, Effects on an afforestation process on plant species richness: A retrogressive analysis. Ecological Complexity 9: 55-62.

Berendse F., 1990, Organic mater accumulation and nitrogen mineralization during secondary succession in heathland ecosystems. Journal of Ecology 78: 413-427.

Berglund B.E. \& Ralska-Jasiewiczowa M., 1986, Pollen analysis and pollen diagrams, [in:] B.E. Berglund (ed.), Handbook of Holocene Palaeoecology and Palaeohydrology. John Willey \& Sons, Chichester: 455-484.

Bernadzki B., Bolibok L., Brzeziecki B., Zajączkowski L. \& Zybura H., 1997, Compositional dynamics of natural stands in the Białowieża National Park over the period 1936-1993. Parki Narodowe i Rezerwaty Przyrody 16: $3-25$.

Björkman L., 1996, The Late Holocene history of beech Fagus sylvatica and Norway spruce Picea abies at stand-scale in southern Sweden. Lundqua Thesis 39. Lund University. Department of Quaternary Geolog., Lund.

Bradshaw R.H.W., Kito N. \& Giesecke T., 2010, Factors influencing the Holocene history of Fagus. Forest Ecology and Management 259(11): 2204-2212.

Braun-Blanquet J., 1964, Pflanzensoziologie. Grundzüge der Vegetationskunde. Wien: Springer. (http://dx.doi. org/10.1007/978-3-7091-8110-2).

Brzeziecki B., 1999, Increase of forest sites generosity formal or real? Sylwan 11: 99-107. 
Filbrandt-Czaja A., Deptuła M. \& Nienartowicz A., 2012, Influence of land cover and structure of tree stands on pollen deposition in Zaborski Landscape Park. Ecological Questions 16: 41-49.

Flinn K.M. \& Vellend M., 2005, Recovery of forest plant communities in post-agricultural landscapes. Frontiers in Ecology and the Environment 3: 243-250.

Hajder K., 2005, Quality classification of pine as an indicator of habitat diversity in forest ecosystems of the Rytel Forest Division. Master Thesis. Nicolaus Copernicus University, Faculty of Biology and Earth Sciences, Department of Soil Science. Torun.

Hicks S., Ammann B., Latałowa M., Pardoe H. \& Tinsley H., 1996, European Pollen Monitoring Programme: project Description and Guidelines. Oulu University Press, Oulu, Finland.

Hicks S. \& Hyvärinen V.P., 1986, Sampling modern pollen deposition by means of Tauber traps: some considerations. Pollen et Spores 28: 219-242.

Huntley B. \& Birks H.J.B., 1983, An Atlas of past and present pollen maps for Europe: 0-13000 years ago. Cambridge University Press, Cambridge.

Jackson S.T., 1990, Pollen Source area and representation in small lakes of the Northeastern United States. Review Palaeobotany and Palynology 63: 53-76.

Janssen J.G.M., 1975, A smple clustering procedure for preliminary classification of very large sets of phytosociological relevés. Vegetatio 30: 67-71.

Koerner W., Dupouey J.L., Dambrine E. \& Benoit N., 1997, Influence of past land use on the vegetation and soils of present days forest in the Vosges mountains, France. Journal of Ecology 85: 351-358.

Kowalski M., 1992, Ecological succession in Polish Forests. Folia Forestalia Polonica, Series A - Forestry 34: 5-18.

Kozikowski A., 1911, History of forests in Royal Prussia in the light of truth. Sylwan 29(8): 337-350.

Latałowa M., Ralska-Jasiewiczowa M., Miotk-Szpiganowicz G., Zachowicz J. \& Nalepka D., 2004, Fagus sylvatica - Beech, [in:] M. Ralska-Jasiewiczowa, M. Latałowa, K. Wasylikowa, K. Tobolski, E. Madejska, H.E. Wright, Jr, Ch. Turner (eds), Late Glacial and Holocene history of vegetation in Poland based on isopollen maps. W. Szafer Institute of Botany, Polish Academy of Sciences, Kraków: 95-104.

Lauschner Ch. \& Rode M.W., 1999, The role of plant resources in forest succession: changes in radiation, water and nutrient fluxes, and plant productivity over a 300-yr-long chronosequence in NW-Germany. Perspectives in Plant Ecology, Evolution and Systematics 2(1): 103-147.

Manning P., Putwain P.D. \& Webb N.R., 2004, Identifying and modeling the determinants of woody plant invasion of lowland heath. Journal of Ecology 92: 968-881.
Matuszkiewicz J.M., 2007, Changes in dry and typical pine forests in the West part of Bory Tucholskie, [in:] J.M. Matuszkiewicz (ed.), Geobotanical identification of the development tendencies in forest associations in the regions of Poland. Polish Academy of Sciences, Stanisław Leszczyński Institute of Geography and Spatial Organizations, Warszawa: 96-116.

Matuszkiewicz W., 2008, Przewodnik do oznaczania zbiorowisk roślinnych Polski [A guide for identification of plant communities in Poland]. PWN, Warszawa.

Olaczek R., 1990, Response of acidophilous beech forest to clear cutting, [in:] A. Szujecki (ed.), Functioning of forest ecosystems under conditions of various kinds of anthropopressure. Wydawnictwo SGGW-AR, Warszawa: $15-16$.

Pidek I.A., Filbrandt-Czaja A., Noryskiewicz A.M., Noryskiewicz B. \& Räsänen S., 2009, New methods applied to interpretations of pollen data in the Holocene - selected examples from the last decade. Ecological Questions 11: 49-64.

Poska A. \& Pidek I.A., 2010, Pollen dispersal and deposition characteristics of Abies alba, Fagus sylvatica and Pinus sylvestris, Roztocze region (SE Poland). Vegetation History and Archaeobotany 19: 91-101.

Puchalski T. \& Prusinkiewicz Z., 1975, Ekologiczne podstawy siedliskoznawstwa leśnego [Ecological basis for forest habitat classification]. Państwowe Wydawnictwo Rolnicze i Leśne, Warszawa.

Rode M.W., 1999a, Influence of forest growth on former heathland on nutrient input and its consequences for nutrition and management of heath and forest. Forest Ecology and Management 114: 31-43.

Rode M.W., 1999b, The interaction between organic layer and forest growth and forest development on former heathland. Forest Ecology and Management 114: 117-127.

Sokołowski A.W., 1965, Forest associations of the Laska Forestry District in Bory Tucholskie (Tuchola Forest). Fragmenta Floristica et Geobotanica XI (1): 97-119.

Sokołowski A.W., 1991, Changes in species composition of a mixed Scots Pine-Norway spruce forest at the Augustów Forest during the period 1964-1987. Folia Forestalia Polonica, Series A - Forestry 33: 5-23.

Sokołowski A.W., 1993, Changes in species composition of forest plant communities induced by industrial emission in NE Poland. Poradnik. Prace Muz. Szafera 7/8: 27-39.

Sugita S., 1994, Pollen representation of vegetation in quaternary sediments: theory and method in patchy vegetation. Journal of Ecology 82: 881-897.

Sugita S., 1998, Modelling pollen representation of vegetation. Palaeoclimate Research 27: 1-16.

Sugita S., Gaillard M.J. \& Broström A., 1999, Landscape openness and pollen records: a simulation approach. Holocen 9: 409-421. 